\title{
PRINCIPAL NEW ZEALAND EARTHQUAKES IN 1990
}

\author{
Warwick D. Smith1
}

\begin{abstract}
During 1990 there were three shallow earthquakes which approached or exceeded magnitude 6 . They were all felt very strongly, though damage was not extensive.
\end{abstract}

on February 10 there was an earthquake of magnitude 5.8 centred near Lake Tennyson, just north of Hanmer in North Canterbury. It was followed within 30 minutes by two large aftershocks, of magnitudes 5.5 and 5.3 . Three hours later there was another, of magnitude 5.0. There are vivid eyewitness accounts from climbers in the mountains overlooking Lake Tennyson, who report that sections of the ridge they had recently been standing on were shaken down in the aftershocks. In forested areas, the earthquake caused healthy beech trees to snap off at a surprisingly constant height of 1.5 metres above the ground. A field survey using portable digital seismographs was mounted, and in one week recordings of over 4000 aftershocks were obtained. The three nearest stations of the national network were also particularly useful for this sequence: Tophouse, Kaikoura and near Lake sumner.

Nine days later, there was another of similar size in southern Hawke's Bay of magnitude 5.9 and located near weber, east of Dannevirke. It was followed on May 13 by a larger event $(6.3)$ to which it was clearly related. The February shock was at a depth of $34 \mathrm{~km}$ and had a tensional mechanism. It was caused by tension in the subducting Pacific plate as it is being drawn down beneath the North Island. But this tensional earthquake actually increased the compressive stress in the overriding plate, thus triggering the compressional earthquake which eventually occurred in May. Aftershocks of these two were not as prolific as in the Lake Tennyson sequence, but there was one of magnitude 5.6 on August 16.

This phenomenon of one earthquake being followed a few months later by another, larger event, is one which has been observed elsewhere. The Loma Prieta earthquake in california in october 1989, of magnitude 7.1 , was preceded several months earlier by a smaller shock. There have been similar instances in China. It presents a challenge to seismologists: can earthquakes which will be followed by larger ones be identified as such and be distinguished from moderate ones which occur in their own right? A clue may

DSIR Geology and Geophysics

$P$ O Box 1320, Wellington

(Fellow, NZNSEE) be in the characteristics of the aftershock sequence which follows the first earthquake, and this will be an area of investigation at the seismological observatory in the near future.

Damage, in Dannevirke, the nearest town of any size, was surprisingly light. The epicentral distance was about $20 \mathrm{~km}$ for both earthquakes, and one might have expected damage, especially to old brick structures of which there are very many in the town. Detailed reports are available from engineers who visited immediately after the earthquake.

After the May 13 earthquake, an experiment was conducted to assess the effects of different soil conditions on intensities experienced in the wellington region. A request for information on the severity of shaking, published in the Evening Post, brought nearly 3000 responses. Analysis of these results indicated markedly higher intensities on the areas of poorly consolidated sediments of Wellington and the Hutt valley, and especially the sandy areas of the coastal strip from Paekakariki to Waikanae. Lower intensities were experienced in the hill suburbs. These were all moderate intensities, of course, up to MM VI. Extrapolation of the results to higher intensities needs to be done with caution.

There were 14 earthquakes of magnitude 5.0 or greater in the New Zealand region (south of $35^{\circ} \mathrm{S}$ ) : four were part of the Lake Tennyson sequence, four were near Weber, and four were to the north and east of the Bay of Plenty - East cape region. The remaining two were in Jackson's Bay, north Fiordland, on July 10 (magnitude 5.1), and off Cape Palliser on October $6(5.0)$.

The Cape Palliser sequence (from October 5 to 15) caused some alarm in the wellington region. The october 6 shock displaced some goods from shelves in some southern Wairarapa localities, and there were reports of its being felt quite strongly in parts of Wellington.

There were also 13 earthquakes of magnitude 5.0 or more that were at depths of more than $100 \mathrm{~km}$. Because they were so deep, felt effects were very modest, although reports came from widely spread locations.

It is not particularly common for earthquakes to be felt in greater Auckland, but on 21 December there was a shock of magnitude 4.1 on the Hauraki plains which was reported felt in Papakura. It was felt most strongly in Morrinsville and Te Aroha. 